\title{
KEEPING THE FAITH: THE UNIVERSITY EXPERIENCE AND APOSTASY
}

\author{
J. PAUL GRAYSON \\ YORK UNIVERSITY
}

$\mid$

\begin{abstract}
In 1963, Glendon College, York University, located in Toronto Canada, admitted mainly Christian students of European origin to a small liberal arts program. Fifty years later the College remained small with a continuing, but less embracive, commitment to the liberal arts; however, the student body included large numbers of young adults who professed religions other than Christianity and came from backgrounds other than European. Within this context, this article focuses on the impact of the Glendon College experience on students' religious identification and participation in religious services. Overall, I find that in the mid-sixties the College experience contributed to changes in the religious identification of students. By contrast, a halfcentury later, students' post-secondary experiences were of little consequence for religiosity. One possible explanation for differences in the College effect is that because of the current racial and religious diversity of Toronto, students are more likely than in the past to confront their religious identities in high school. Keywords: liberal arts, religiosity, change, university experience

\section{Résumé}

En 1963, le collège Glendon de l'Université York, qui est située à Toronto, au Canada, admettait essentiellement des étudiants chrétiens d'origine européenne dans son petit programme d'arts libéraux. Cinquante ans plus tard, le collège était toujours de taille modeste, avec un engagement continu, bien que moins vaste, à l'égard des arts libéraux. Cependant, le corps étudiant comprenait de nombreux jeunes adultes pratiquant une religion autre que chrétienne et issus d'horizons autres qu'européens.

Dans ce contexte, cet article se penche sur le rôle de l'expérience au collège Glendon dans l'identification religieuse des étudiants et leur participation aux offices religieux. De manière générale, je constate qu'au milieu des années soixante, l'expérience vécue au collège avait un effet transformateur sur l'identification religieuse des étudiants. Par contraste, un demi-siècle plus tard, l'expérience d'études postsecondaires des étudiants avait peu de conséquences sur leur pratique religieuse. Une explication possible de cette différence relativement à l'effet du Collège réside dans la diversité raciale et religieuse que l'on observe actuellement à Toronto, qui fait en sorte que les étudiants sont plus susceptibles que par le passé de s'interroger sur leur identité religieuse dès l'école secondaire.
\end{abstract}

Mots-clés : arts libéraux, religiosité, changement, expérience universitaire

\section{Introduction}

In 1961, 95\% of Torontonians were of European origin. Fifty two percent $(52 \%)$ were Protestant (Dominion Bureau of Statistics, 1961a, pp. 87-26; 1961b, pp. 83-30). By 2011 the figures were $51 \%$ and $12 \%$, respectively (City of Toronto, 2013). In the intervening years, Toronto had become one of the most ethnically and religiously diverse cities in the world. While the nature of Toronto had been radically transformed, one of its educational institutions, Glendon College, York University, remained a small liberal arts college.

In this article I will focus on the student cohorts entering Glendon in 1963 and 2013 and examine the extent to which the college experience affected their religiosity. I will argue that in both eras a minority of graduates rejected the religious identification of their parents. Much of the change for the cohort of 1963 can be attributed to 
students' experiences at Glendon; however, changes in religious identification in the 2013 cohort predated college entry. One possible explanation for these differences is that Toronto is now more racially and religiously diverse than in the past. As a result, it is possible that some current students confront-and change-their religious identities prior to university.

This study is unique. There are no other Canadian universities for which similar information is available for students in the sixties and in the second decade of the twenty-first century. Unfortunately, we do not know if the processes observed at Glendon were, or are, extant on other Canadian campuses. This is not a limitation; in historical sociology, analyses like the current one are common.

\section{The Approach}

In supporting my argument, I utilize the theoretical and methodological tools of the historical sociologist, and many social historians (Calhoun, 1998; Lachmann, 2013; Mahoney, 2004). Although researchers with this orientation often focus on large scale events such as revolutions and other social transformations, their approach can also be applied to more mundane phenomena. Consistent with this possibility, in this article I support my argument by means of a modified strategic narrative. Although it may be difficult to find pure examples of this technique, according to Stryker (1996, p. 395), strategic narratives "organize material into chronological order to tell stories about what happened." Often, such narratives "follow Weber in seeking interpretative and causal understanding of historical happenings treated as valid objects of social science inquiry in their own right [emphasis added]." In other words, historical events are not just viewed as data to test, or to link to, pre-existing theories (Platt, 2007, p. 354).

In this study, as in much research involving historical comparisons, analysis is limited by information available in documentary sources. In consequence, while in an ideal study including surveys, religious concepts and behaviours would be defined and then operationalized in ways consistent with the needs of current researchers, this luxury is unavailable for the past. As a result of limitations such as this, contemporary researchers must often rely on the operationalizations and coding practices of their predecessors. Given this reality, if historical comparison is the objective, the operationalizations of contemporary researchers may be constrained by those of their predecessors, even if the result is less than ideal. Limitations resulting from these and other considerations will be identified as I make my argument.

\section{The Impact of University on Religion in the United States}

Before making my argument, it is important to briefly summarize what we know about the effect of a higher education on different aspects of religiosity. Unfortunately, in Canada, this information is sparse. As a result, it is helpful to look at American studies. When so doing we must recognize that the development and current nature of religion in each society was/is different. More will be said of this later.

Bearing this caveat in mind, I will begin with a 1977 observation of Caplivitz and Sherrow. They argued that the in the middle of the twentieth century, the American university was "a breeding ground for apostasy" (1977, p. 109). There were numerous studies that had supported, and would continue to sustain, this conclusion (Hunsberger \& Brown, 1984; Hunter, 1983; Willits \& Crider, 1989).

Most students entered university as Christians and, to a lesser extent, Jews. Unlike many who terminated their studies at the primary or secondary levels, a good number left their campuses as atheists or agnostics. Former belief systems often could not withstand students' confrontations with novel ideas and different people.

In the past few decades, the situation has changed. While some studies continue to identify an apostatizing effect of university (Hurtado et al., 2007; Lee et al., 2004), others have shown that the religious beliefs and behaviours of the college educated are more intense and durable than those of Americans without a post-secondary education (Maryl \& Uecker, 2011; Uecker et al., 2007).

Although in this article American studies provide the main point of departure, it is important to note that British evidence points to conclusions similar to the above. In a national study Guest et al. (2013) show that universities do not exert a secularizing influence on contemporary British students. Unfortunately, credible information on prior eras is unavailable.

In an effort to pin down the point at which the apos- 
tatizing effect of post-secondary education ceased in the United States, Schwadel (2014) utilized the results of General Social Surveys from 1973 to 2010. He found that among birth cohorts of the first half of the twentieth century higher education had a decreasing negative effect on religious affiliation. This changed for the birth cohort of 1965-69. For this group, the effect was nil. For subsequent cohorts, the post-secondary experience led to an increase in religious affiliation (p. 733). Independent of this trend, most Americans (85\%) continued to profess religious beliefs similar to those of their parents (Minn et al., 2018).

Not all students were equally likely to experience a weakening or rejection of religious beliefs. Mainline Protestants and Catholics were the most susceptible to change (Uecker et al., 2007, p. 1676). Students pursuing degrees in the Humanities and Social Sciences were more vulnerable to the pulls of disaffiliation than those completing studies in other fields. In addition, it is likely that graduates of religious high schools approached higher education in ways different from those who received a secular secondary education (Hill, 2009).

How do we account for the fact that in the United States in recent decades the connection between higher education and various aspects of religiosity has changed? Several possible explanatory factors have been identified. Each can be linked to specific historical developments.

1. Over time, students' reasons for engaging in higher education have become more practical. As a result, while pursuing their degrees, they are less likely than before to question their religious beliefs (Uecker et al., 2007, p. 1669).

2. According to Uecker et al., "the arrival of postmodern, post-positivist thought on university campuses has served to legitimize religiosity and spiritually, even within intellectual circles" (Uecker et al., 2007, p. 1684).

3. Changing, and more inclusive, admission policies have resulted in the enrollment of students who are increasingly more representative of the religions of the American population (Maryl \& Uecker, 2011, p. 201).

4. Students increasingly self-segregate into different moral communities while in university
(Schmalzbauer, 2007). In consequence, they are either not exposed to, or manage to fend off, challenges to their faiths.

5. The number of church-goers with higher education has increased. As a result, the less educated may have become alienated from many congregations. The result is disaffiliation (Schwadel, 2014, pp. 722-723).

\section{Religion in Canada and the United States}

Unfortunately, Canadian studies such as the foregoing are unavailable. As a result, although we can utilize the findings of U.S. studies as a point of departure, we must exercise caution in how we use them.

In Canada religion took a different trajectory than in the United States. In the latter, religion was shaped by the anti-statist beliefs of early Protestant settlers (Lipset, 1990, p. 74; 1996, pp. 91-92). By contrast, Canada's religious tradition was defined by hierarchical churches with close state ties (p. 80). As a result, Canadians more readily than Americans accepted the need for state authority in various areas of activity (pp. 41, 80).

Different roles assumed by the state were particularly evident in the realm of education. In the United States, religious instruction was prohibited in publicly funded schools. In Canada, in various provinces, the state supported both Protestant and Catholic systems of education (Eisgruber \& Zeisberg, 2006, p. 225). Moreover, until the middle of the twentieth century, state and civil society in the Province of Quebec were under the grip of the Roman Catholic church (Gauvreau, 2005). There was no parallel in the United States.

By the end of the twentieth century, Lipset argues that Americans were far more devout than Canadians (Lipset, 1990, p. 4). This trend continues. In 2011, 20\% and $24 \%$ of Americans and Canadians respectively reported religious non-affiliation (Pew Research Center, 2013 , p. 3). In 2012, $46 \%$ of Americans indicated that in the previous year they had attended religious services at least once a month. The figure for Canadians was much lower, at $27 \%$ (p. 5). While in both Canada and the United States the majority religions remain Christian, the numbers of Canadians reporting other religions (11\%) was almost double that of the United States (6\%) (p. 4). 
Notwithstanding the foregoing, religious non-affiliation is on the rise among American youth. The same is true in Canada. Among the cohort of Canadians born in 1987 to $1995,29 \%$ reported allegiance to no religion. For Canadians with birth dates of 1946 or earlier the figure was a much lower 12\% (Pew Research Center, 2013, p. 6). In contrast to some of the American findings, religious non-affiliation was a bit higher among college graduates (23\%) than among others (21\%) (Pew Research Center, 2013 , p. 6). Scholars disagree on the degree to which the foregoing figures point to an increasing secularization of Canadian society (Bibby, 2015; Thiessen, 2015).

It is worth noting that the current percentage of American Evangelicals (25\%) (Pew Research Center, $2018)$ is more than double the number in Canada $(10 \%)$ (Hiemstra \& Stiller, 2016). This difference is important for two reasons. First, in American studies, Evangelicals have been relatively steadfast in their beliefs over the course of their university careers and less likely than others to curb their religious attendance (Uecker et al., 2007, p. 1677). Second, despite a general decline in campus ministries, those of Evangelical faiths have increased (Schmalzbauer, 2007). As a result of these differences Canadian students, more than their American peers, may be spared a strong moralizing influence on many campuses.

\section{Glendon College}

The original campus of York University, Glendon College, was located in what is now mid-town Toronto on a beautiful large treed estate originally owned by Edward Wood, a leading Canadian financier of the early twentieth century (Grayson, 2019). Although it opened its doors in 1959 , degrees were originally granted through the University of Toronto. The first students eligible for a York degree enrolled in 1963 (Horn, 2009). Shortly thereafter, a much larger main campus was opened on the outskirts of the City, approximately 19 kilometers from the founding site.

While York University has grown exponentially, Glendon remains small. Administrative records show that two hundred and ninety-six (296) students enrolled in first year in 1963. In 2013 their number increased to 522. While this figure represents a $76 \%$ increase the absolute numbers are small.

York University (and Glendon College) was original- ly characterized by its first President as, "a university devoted to liberal and general education, and we operate on the premise that all specialists should have a foundation of education which provides some understanding of themselves as persons, some understanding of the political system to which they profess allegiance, some understanding of the world in which they live" (Ross, 1961, p. 25). Over the years, the emphasis on general education has diminished at both York in general and at Glendon in particular. This said, Glendon still identifies itself as a liberal arts college with a twist. According to a recent Principal, "Glendon now extends its mandate by infusing liberal arts thinking into professional programs such as translation, conference interpretation, and soon, more professional, as well as scientific disciplines" (Glendon College, 2017). Consistent with this orientation, students are still expected to complete certain general education requirements; nonetheless, demands are fewer than fifty years ago.

While Glendon College remains small, and its current curriculum retains a connection to general education and the liberal arts, the composition of its student body has changed drastically. Although administrative records show that in 1963 approximately half $(47 \%)$ of students entering Glendon were female, by 2013 the figure had swelled to $78 \%$. In 1963 both male and female students entering the College were overwhelmingly of European origin. In a survey of 2013 (more later) a majority of students (58\%) identified as White. A further $9 \%$, $12 \%$, and $13 \%$ considered themselves Latin American, South Asian, and Black respectively.

\section{General Education}

It is important to note that for students entering Glendon in 1963, aspects of religion (mainly, but not exclusively, Christianity) were mandatory parts of the curriculum, largely through courses in the Humanities. All students entering in 1963 were required to take Humanities I: The Roots of Western Civilization. The description of the course in the York University Calendar for 1963-64 included the following:

Materials to be studied include documentary sources (e.g. the Rule of St. Benedict), works of history and criticism, works of art and architecture in reproduction, and great works of literature, philosophy, and religion in translation (including selection from the 
Bible, Homer, Sophocles, Plato, St. Augustine, and Dante).

As well as mandatory exposure to religion in humanities courses, students explored examples of religious reasoning in a required course in Modes of Reasoning.

While in 2013 to 2017 students still had the obligation of completing courses in general education, options available to fulfill this requirement had changed. An examination of current courses at Glendon identified as general education revealed few with a clear religious focus. Exceptions included history courses on the "European Reformation" and "Renaissance Italy"; and sociology offerings on "Religion and Society" and "Religion, Media, and Culture."

\section{Religion on Campus}

While at the global level important religious debates, like Vatican II, were taking place, and religion was a mandatory component of certain courses (Grayson, 2011), between 1963 and 1967, at Glendon, as revealed in the student newspaper, ProTem, religion was not an important component of public discourse. In 1963, for example, there was only one exchange between students in the newspaper involving religion. In this instance a student wrote of hypocrisy, including religious hypocrisy, pervading contemporary life, and the fact that religion was divorced from reality. "Surely," the writer reasoned, "If the church is to bear any relevance to life it must be applicable in real situations" (Bell, 1963, p. 5). The following week a student submitted a reply in which he challenged the cynicism of the earlier article.

If religion was infrequently mentioned in ProTem in the years 1963 to 1967, it was virtually ignored from 2013 to 2017. Indeed, the word "religion" itself was only raised in eight articles! In only one of these was it the focus of the discussion. In this instance, Tori Ramsay informed the campus LGBTQ community that she was sorry "for how 'Christians' may have treated you in the past." She felt that "it is okay that we are different." In particular, she wanted to assure the community that "we are not all judgmental and ignorant." (Ramsay, 2013, p. 5). In contrast to its neglect of religion, the paper published many articles on sex and sexual identity (Grayson, 2019). This topic had been completely absent from the pages of ProTem from 1963 to 1967.

\section{Sources of Information}

Some of the information for the remainder of this article comes from three surveys. A first survey was mailed in 1967 to all students who entered Glendon in 1963 and who graduated by 1967 (78 male and 57 female respondents); a web survey that was made available to all students entering their first year in 2013 (50 male and 173 female replies); and a similar web survey was carried out four years later in 2017 (12 male and 80 female participants). In view of the relatively small number of males in the survey of 2017, all comparisons using this group will be treated cautiously.

The 1967 questionnaire was mailed to all 190 students eligible to graduate in that year. The 2013 survey instrument was sent to all 522 new enrollees. In 2017 all students of the 2013 cohort who were still registered, 326, were included in the sample. I have shown elsewhere that the samples of both 2013 and 2017 are representative of the populations from which they were derived (Grayson, 2019). Unfortunately, only $39 \%$ of students completing the 2017 survey had done so in 2013. As a result, each survey will be viewed as a separate survey of the same population. This is not a panel study.

The response rates for the surveys of 1967, 2013, and 2017 were $71 \%, 43 \%$, and $28 \%$ respectively. While the response rate for the last survey was relatively low, by contemporary standards, it was more than acceptable. For example, in 2017, the average Canadian response rate to the U.S. based National Study of Student Engagement (NSSE) was $37 \%$. In the United States it was a lower $30 \%$ (NSSE, 2018).

Relatively low response rates such as the foregoing, which are now common in studies of students, have led researchers to reconsider some preconceptions. Previously, there was a general belief that low response rates were synonymous with bias; however, recent research based on a large number of university samples has found this to be an unfounded assumption (Fosnacht et al., 2017).

As those completing the 1967 and 2017 surveys had either finished their degree requirements or four years of education, in the remainder of this article, they will be referred to as graduates. 


\section{Measurement}

The 1967 survey was conducted by Dr. Dee Appley of the Department of Psychology at Glendon. Unfortunately, while she collected the data, Dr. Appley did not analyze it; however, much of her information has recently been analyzed to good effect (Grayson, 2011, 2014, 2015, 2018a, 2018b, 2019). These articles contain additional material on various methodologies employed that, because of space constraints, could not be included in this article.

Among questions Dr. Appley asked of Glendon students in 1967, one focused on potential changes in religious beliefs. More specifically, in an open-ended question, students were asked, "Have there been any significant changes in your beliefs since you were a freshman at York? Consider changes in degree of affiliation, emphasis, etc., and indicate, if possible, when these changes took place and what you think accounts for them." Responses to this question were coded by the original researchers in 1967. This open-ended question was preceded by one in which students were asked their, their mother's, and their father's religion.

In the entry survey of 2013 respondents were only queried about their own religious identification. Four years later, in 2017, they were asked many of the same questions as in 1967. The above open-ended question and queries about their, their mother's, and their father's religion were included among them.

\section{Analysis}

The following analysis will proceed in four steps. First, I will compare the degree to which the religions of Glendon students reflected the faiths of Toronto residents. Second, I will examine various aspects of the religiosity of students in 1967 and 2017. Third, I will compare students' religions to those of their parents. Finally, I will examine the religious attendance of students of different faiths.

\section{Population Comparisons}

As seen earlier, American researchers have recently argued that, more so than in the past, university students' religious identifications reflect those of Americans in general. This observation has been used in efforts to explain the decreased secularization of undergraduates over several decades.
We see in Table 1 that the religious faiths of Glendon graduates of 1967 were not representative of the religious preferences of Torontonians as identified in the 1961 Census of Canada (Dominion Bureau of Statistics, 1961 b, pp. 87-26,27). This finding is similar to those of American studies of the era. Most noticeable is that only $5 \%$ of the graduates of ' 67 were Roman Catholic. By comparison, $35 \%$ of Torontonians followed the Church of Rome. This difference was statistically significant. The finding reflects the reality that, outside of Quebec, the Canadian establishment during this period was Protestant (Porter, 1965).

Although the option of no religion or atheist/agnostic was not available in the 1961 census, it has been estimated that $.5 \%$ of Canadians would have fallen in this category (Roberts et al., 2005, p. 366). In the census report no Torontonians were separately classified as Muslin, Hindu, Christian Orthodox, Sikh, or Buddhist. Their numbers at Glendon were zero. Differences in the number of Jews (5\%) at Glendon, and in the City (3\%), were not statistically significant.

A half century later the situation was radically different. The religious characteristics of students who entered Glendon in 2013 differed little from those of Torontonians in general. The only categories in Table 1 for which differences were statistically significant were for "no religion" and Sikh.

In the census of $2011,24 \%$ of City residents had reported no religion. By contrast, $31 \%$ of the students entering first year in $2013 \mathrm{had}$ no religious faith. Whereas $1 \%$ of Toronto's residents were Sikhs, the figure for those entering first year was $4 \%$. In contrast to 1961 , in which only $7 \%$ of the enumerated may not have been Christian ("other" and Jewish in the Table), by 2011, the number was $56 \%$.

\section{Temporal Comparisons}

Table 2 summarizes the religious preferences of male and female students for the graduating class of 1967, the entry cohort of 2013, and graduates of 2017. Note that in comparison to Table 1, religion has been collapsed into four categories to facilitate meaningful statistical comparisons: "None" (no religion, atheists, and agnostics), "Protestant," "Roman Catholic," and "Other" (Muslims, Jews, Sikhs, etc.). 
Table 1. Comparisons Between Religion of Torontonians and Glendon Students Entering First Year

\begin{tabular}{|c|c|c|c|c|c|}
\hline & $\begin{array}{c}\text { A } \\
\text { Toronto } 1961\end{array}$ & $\begin{array}{c}\text { B } \\
\text { Glendon } 1967\end{array}$ & $\begin{array}{c}\text { C } \\
\text { Toronto } 2011\end{array}$ & $\begin{array}{c}\text { D } \\
\text { Glendon } 2013\end{array}$ & $\begin{array}{c}\text { E } \\
\text { Glendon } 2017\end{array}$ \\
\hline Catholic & $35 \%$ & $5 \%$ & $28 \%$ & $23 \%$ & $26 \%$ \\
\hline No Religion* & & $38 \%$ & $24 \%$ & $31 \%$ & $39 \%$ \\
\hline Protestant & $52 \%$ & $53 \%$ & $12 \%$ & $14 \%$ & $11 \%$ \\
\hline Muslim & & & $8 \%$ & $9 \%$ & $4 \%$ \\
\hline Other & $4 \%$ & & $10 \%$ & $8 \%$ & $4 \%$ \\
\hline Hindu & & & $6 \%$ & $4 \%$ & $2 \%$ \\
\hline Christian Orthodox & $6 \%$ & & $4 \%$ & $2 \%$ & $4 \%$ \\
\hline Jewish & $3 \%$ & $5 \%$ & $4 \%$ & $2 \%$ & $2 \%$ \\
\hline Sikh & & & $1 \%$ & $4 \%$ & $5 \%$ \\
\hline Buddhist & & & $3 \%$ & $3 \%$ & $3 \%$ \\
\hline Column Total & $100 \%$ & $101 \%$ & $100 \%$ & $100 \%$ & $100 \%$ \\
\hline Number & 672,407 & 132 & $2,511,085$ & 180 & 80 \\
\hline \multicolumn{6}{|c|}{ *No religion; atheist; agnostic } \\
\hline $\begin{array}{l}\text { Z-score test for two po } \\
\text { Catholic A, B; No R }\end{array}$ & $\begin{array}{l}\text { s sig. .05 } \\
\text {, D; C, E }\end{array}$ & $D, E$ & & & \\
\hline
\end{tabular}

\section{The Class of ' 67}

It is clear from Table 2 that in 1967 a large minority of graduating students (37\%) reported no religion. A plurality (52\%) were Protestant. Only $4 \%$ of students were Roman Catholic. The remaining 7\% identified with other religions. For none of these religious identifications were differences between males and females statistically significant.

Unfortunately, similar information on religious identification was not available for 1963 . As a result, the impact of the 1963 to 1967 college experience on religiosity was not readily apparent. This limitation was partially offset by analyzing responses to the previously mentioned open-ended question in the 1967 survey: "Have there been any significant changes in your beliefs since you were a freshman at York? Consider changes in degree of affiliation, emphasis, etc., and indicate, if possible, when these changes took place and what you think accounts for them."

Responses to this question were coded by the original researchers in 1967. Once the open-ended question had been coded, in 1967, 34\% of students reported no change in their religious beliefs over the course of their studies. An additional $37 \%$ referred to a change away from religion. Only $10 \%$ indicated that their religious commitment had increased. Nineteen percent of responses were unclassifiable. These figures indicate that between 1963 and 1967 the net decrease in religiosity was 27\% (37\%-0\%) (Grayson, 2011, p. 101).

The uncoded responses to the same open-ended question had shown that, of students who moved away from religion, substantial numbers credited two aspects of the college experience for their change: an increase in their knowledge and interactions with others on campus (Grayson, 2011, p. 101). For some students, the connection between an increase in knowledge and a move away from religion was linked to insights gained from major intellectuals. "I disassociated myself from church after 13 years constant attendance," wrote a male student professing no religion. "Although not a believer," he wrote, "thanks to Albert Camus and the twentieth century in general, I still maintain a vital interest in Christianity and follow its internal struggles closely." Like him, a fe- 
Table 2. Religious Preference by Sex and Year

\begin{tabular}{|c|c|c|c|c|c|c|c|c|c|c|}
\hline & & 1967 & & & & 2013 & & & 2017 & \\
\hline & $\begin{array}{c}\text { A } \\
\text { Male }\end{array}$ & $\begin{array}{c}\text { B } \\
\text { Female }\end{array}$ & $\begin{array}{c}\mathrm{C} \\
\text { Total }\end{array}$ & & $\begin{array}{c}\text { D } \\
\text { Male }\end{array}$ & $\begin{array}{c}\text { E } \\
\text { Female }\end{array}$ & $\begin{array}{c}\mathrm{F} \\
\text { Total }\end{array}$ & $\begin{array}{c}G \\
\text { Male }\end{array}$ & $\begin{array}{c}\mathrm{H} \\
\text { Female }\end{array}$ & $\begin{array}{c}\text { I } \\
\text { Total }\end{array}$ \\
\hline None & $35 \%$ & $40 \%$ & $37 \%$ & & $37 \%$ & $29 \%$ & $31 \%$ & $55 \%$ & $36 \%$ & $39 \%$ \\
\hline Protestant & $55 \%$ & $47 \%$ & $52 \%$ & & $16 \%$ & $14 \%$ & $14 \%$ & $9 \%$ & $12 \%$ & $11 \%$ \\
\hline $\mathrm{RC}$ & $4 \%$ & $5 \%$ & $4 \%$ & & $21 \%$ & $24 \%$ & $23 \%$ & $9 \%$ & $29 \%$ & $26 \%$ \\
\hline Other & $6 \%$ & $7 \%$ & $7 \%$ & & $26 \%$ & $33 \%$ & $32 \%$ & $27 \%$ & $23 \%$ & $24 \%$ \\
\hline & $100 \%$ & $100 \%$ & $100 \%$ & & $100 \%$ & $100 \%$ & $100 \%$ & $100 \%$ & $100 \%$ & $100 \%$ \\
\hline & 78 & 57 & 127 & & 38 & 142 & 268 & 11 & 69 & 80 \\
\hline & & & & & Fisher's & xact Test & & & & \\
\hline & & $\begin{array}{c}\text { A, B } \\
0.815\end{array}$ & & $\begin{array}{c}\mathrm{D}, \mathrm{E} \\
0.744\end{array}$ & & & $\begin{array}{c}\text { G, H } \\
0.507\end{array}$ & $\begin{array}{c}A, G \\
0.007\end{array}$ & & $\begin{array}{l}\text { B, H } \\
0.000\end{array}$ \\
\hline & & $\begin{array}{c}\mathrm{D}, \mathrm{G} \\
0.320\end{array}$ & & $\begin{array}{c}\mathrm{E}, \mathrm{H} \\
0.342\end{array}$ & & & $\begin{array}{c}C, I \\
0.000\end{array}$ & $\begin{array}{c}F, I \\
0.413\end{array}$ & & \\
\hline
\end{tabular}

male Protestant student indicated that at Glendon, "religion was one area that I really began to think about. Now I think, like Pascal, that believing in God is a good risk-I have nothing to lose." "Dabbling in the works of Herbert Marcuse," wrote a non-religious male student, "has made me critical of any and all restrictive ideologies, either Christian, capitalist, or Communist."

The original responses to the open-ended question, as well as the coded responses, clearly point to a change in the nature and intensity of religious commitment in the 1963 to 1967 period; however, they cannot be equated with changes in religious identification. For example, a Protestant student may have moved away from her religion. This does not mean that she renounced her faith. It may simply indicate that her religious feelings were weaker than when she entered first year.

Despite the foregoing caveat, the overall evidence suggests that the net effect of the university experience on religiosity for the cohort of 1963 was negative. This conclusion is consistent with Caplivitz's and Sherrow's characterization of the American university of the era as "a breeding ground for apostasy" (1977, p. 109). The answers to the un-coded open-ended question show that the university experience, including the liberal arts curriculum, played a significant role in this process.

\section{The Class of '17}

Table 2 shows that among students entering the College in $2013,31 \%$ professed no religion, $14 \%$ were Protestant, 23\% Roman Catholic, and 32\% reported other religions. Sex-based differences were not statistically significant.

Figures in Table 2 also indicate that in 2017, 39\% of graduates had no religion. A further $11 \%$ identified as Protestant. The remaining $26 \%$ and $24 \%$ were Roman Catholic and Other, respectively. Sex-based differences were not statistically significant.

Consistent with demographic changes in the City of Toronto, there was a statistically significant change in the overall religious preferences of the graduates of 1967 and 2017 (columns C \& I). This said, it is important to note that the number of graduates reporting no religion in 2017 (39\%) was virtually the same as in 1967 (37\%)! The largest difference between the two periods was for the numbers of students of Protestant, Roman Catholic, and other faiths. At Glendon, between 1967 and 2017, 
there was a drastic decline among Protestants from $52 \%$ to $11 \%$; an increase in Catholics from $4 \%$ to $26 \%$; and an increment in Others from $7 \%$ to $24 \%$.

Particularly important is that in likely ("likely" because of data limitations) contrast to the period 1963 to 1967 , differences in religious preferences between 2013 and 2017 were not statistically significant. In other words, despite some fluctuations from one religion to the next, four years of post-secondary education with a liberal arts emphasis had no effect on the religious identification of students at Glendon from 2013 to 2017.

In 2017 the responses to the open-ended question that was used in the 1967 survey were quite different from half a century earlier. In 2017 the most frequently mentioned themes had nothing to do with religion. Instead, attention focused on: a broadening of intellectual horizons (25\%), changes in academic and career direction (19\%), and increases in self-confidence (12\%). Religion was included in only $3 \%$ of comments!

In one of these comments a student remarked, "I joined a religious club on campus and my religious beliefs have definitely gotten stronger." In this case the influence of the club was reinforced through courses that "allowed me to learn about other religions and not just my own." In another case a student revealed that because of her college experience, "I respect humanity more and have more patience." In addition, she revealed that "I also question some religious beliefs because of the historical facts that I have learned." These comments are in sharp contrast to very philosophical answers to the same question made by virtually all responders to the survey of 1967. In view of the limited attention given to religion in students' open-ended comments, it is reasonable to assume that in 2013 to 2017 those at Glendon took their religious identity for granted to a greater extent than their predecessors fifty years earlier. Overall, the campus experience had a negligible effect on the religiosity of contemporary students.

\section{Related Evidence}

There is another finding that contributes to the above impression. In the surveys of 1967 and 2017 respondents were asked to identify the most important of a number of life goals. One of the options was, "developing a meaningful philosophy of life." In 1967 this goal was selected by $24 \%$ of survey responders. The number in 2017 was only $8 \%$. This difference was statistically significant. In other words, Glendon graduates of 1967 had likely spent more time considering religious options than those of 2017.

American studies in which the same question was asked show two things. First, in both the mid-sixties and mid-nineties (granted, a shorter period than the one studied here) the percentages of American students selecting the same goal were far higher than at Glendon. Second, the amount of decline from one period the next was less than experienced at Glendon (Uecker et al., 2007, p. 1669). Both of these points are consistent with the point made earlier that Americans are more devout than Canadians.

\section{Generational Patterns}

American research points to a high degree of continuity between parents' and off-springs' religion (Minn et al., 2018). As a result, in this study, we will assume that at some point prior to university students were of the same faith as their mothers and fathers. On the basis of this assumption we have another measure of the possible effect of the university experience on religious identification.

Previous research indicates that in 1967, 18\% of parents had no religion or were agnostic or atheist (Grayson, 2011, p. 98). By comparison, the figure for graduates was $38 \%$. In other words, after four years at Glendon, $20 \%$ (38\% - 18\%) of students had changed from having a religion to not having one or of becoming an agnostic or an atheist. Protestants lost the most in this process. In total, $17 \%$ of Protestant students moved away from the religions of their parents. Only $3 \%$ of Catholics reported preferences different from those of their mothers and fathers. The remaining students (Jews in this case) remained steadfast in their beliefs.

Similar figures for 2017 are presented in Table 3. Overall, despite absolute differences, there were no statistically significant sex-based differences in the number students committed to specific religions. Also, there was similarity in the religions of mothers and fathers. For example, $29 \%$ of fathers and $27 \%$ of mothers were reported as having an Other religion. Not surprisingly, overall differences between the religious preferences of mothers and fathers were not statistically significant.

Remarkably, when comparisons were made between students and parents we see that, at the end of their studies in 2017, 19\% more students of the 2013 cohort than parents reported having no religion or as being atheist or agnostic. In 1967 the figure had been virtually the same: $20 \%$ ! In comparison to 1967 , however, the 
Table 3. Students' and Parents' Religious Preferences 2017

Students

$\begin{array}{ccc}\text { A } & \text { B } & \text { C } \\ \text { Female } & \text { Male } & \text { Total }\end{array}$

$\begin{array}{lccc}\text { None } & 36 \% & 60 \% & 39 \% \\ \text { Protestant } & 10 \% & 10 \% & 10 \% \\ \text { RC } & 30 \% & 10 \% & 27 \% \\ \text { Other } & 24 \% & 20 \% & 23 \% \\ & & & \\ \text { Total } & 100 \% & 100 \% & 99 \% \\ \text { Number } & 67 & 10 & 77\end{array}$

Fisher's $=.460$
Parents

$\begin{array}{cccc}\begin{array}{c}D \\ \text { Father }\end{array} & \begin{array}{c}E \\ \text { Mother }\end{array} & \begin{array}{c}F \\ \text { Total }\end{array} & \begin{array}{c}\text { Difference } \\ \text { C-F }\end{array} \\ & & & \\ 24 \% & 16 \% & 20 \% & 19 \% \\ 13 \% & 17 \% & 15 \% & -5 \% \\ 35 \% & 40 \% & 37 \% & -10 \% \\ 29 \% & 27 \% & 28 \% & -5 \%\end{array}$

$\begin{array}{ccc}100 \% & 100 \% & 100 \% \\ 72 & 75 & \end{array}$

Fisher's $=.586$
Fisher's $=.024$ greatest decreases in adherents were found not among Protestants, but Catholics (-10\%). The figure for Protestants and Others was $-5 \%$ for each. These differences between the religions of students and parents were statistically significant.

To simplify the implications of these findings, in Table 4, I divided students into those who had changed beliefs in relation to their parents to those who experienced no change. In $1967,40 \%$ and $60 \%$ of students responded that they had experienced change and no change respectively. Small sex-based differences were not statistically significant. Fifty years later, in 2017, the results were virtually the same: $38 \%$ of students had changed; $62 \%$ had not changed after four years of university. These time-based comparisons were not statistically significant. In other words, the degree to which students' religions in 2017 reflected those of their parents was the same as it had been in 1967.

\section{Religious Service Attendance}

So far, attention has focused primarily on religious identification. It is obvious that an individual may profess a particular religion yet fail to participate in activities associated with his or her faith such as praying and attending religious services. While data on these matters is unavailable for the class of ' 67 , information on participation in religious services was collected in the surveys of 2013 and 2017.
In 2012, responses to the Canadian General Social Survey showed that $27 \%$ of all Canadians attended religious services at least once a month (Pew Research Center, 2013, p. 5). The question used in the Survey that yielded this information was also included in the surveys of Glendon students in 2013 and 2017. Students' replies show that in 2013 and $201716 \%$ and 5\% of students respectively attended services at least once a month (not shown in table); however, differences were not statistically significant. In other words, the attendance at services of Glendon students at least once a month was lower than the Canadian average but between year differences were not statistically significant.

In view of the numbers of respondents, response options for the question were collapsed to facilitate comparisons between sexes and survey years. The results are seen in Table 5.

Table data indicate that in neither 2013 nor 2017 were sex-based differences in service attendance statistically significant. Comparisons of totals also reveal no statistically significant differences in service attendance between the two surveys. As a result, we can average the combined total figures as a characterization of the religious attendance of students at Glendon over a fouryear period. (Note that this step involves the means of the frequencies, not the mean of the means.) This procedure reveals that a plurality of students (44\%) reported religious participation of less than once a week. The next 
Table 4. Change in Religious Preference from Parents

A Male Female Total

Change

No Change

$$
42 \%
$$

$37 \%$

$63 \%$

$40 \%$

Total

Cases

$58 \%$

$100 \% \quad 100 \%$

$100 \%$

$78 \quad 57$

135

Fisher's $=.595$

$\mathrm{A}, \mathrm{B}=.770$

Table 5. Frequency of Religious Service Participation by Sex and Year

2013

$\begin{array}{ccc}\text { A } & \text { B } & \text { C } \\ \text { Male } & \text { Female } & \text { Total }\end{array}$

Never

Less Than Once Week

At least once a week

Don't know

Total

Cases

$\begin{array}{ccc}38 \% & 31 \% & 32 \% \\ 38 \% & 49 \% & 47 \% \\ 23 \% & 17 \% & 18 \% \\ 3 \% & 3 \% & 3 \%\end{array}$

$100 \% \quad 100 \% \quad 100 \%$

$40 \quad 147 \quad 187$

Fisher's Exact Test

$\begin{array}{cccccc}\text { Overall } & \text { A, B } & \text { D, E } & \text { A, D } & \text { B, E } & \text { C, F } \\ 0.533 & 0.546 & 0.558 & 0.566 & 0.472 & 0.502\end{array}$


Table 6. Religious Service Participation by Religious Preference and Year

2013

$\begin{array}{ccccc}\text { A } & \text { B } & \text { C } & \text { D } & \text { E } \\ \text { None } & \text { Protestant } & \text { RC } & \text { Other } & \text { Total }\end{array}$

$\begin{array}{lccccc}\text { Never } & 70 \% & 4 \% & 15 \% & 21 \% & 32 \% \\ \begin{array}{l}\text { Less Than Once } \\ \text { Week }\end{array} & 26 \% & 44 \% & 61 \% & 57 \% & 47 \% \\ \begin{array}{l}\text { At least once a } \\ \text { week }\end{array} & 0 \% & 52 \% & 22 \% & 18 \% & 18 \% \\ \begin{array}{l}\text { Don't know } \\ \text { Total }\end{array} & 4 \% & 0 \% & 2 \% & 4 \% & 3 \% \\ \text { Cases } & 100 \% & 100 \% & 100 \% & 100 \% & 100 \% \\ & 53 & 25 & 41 & 56 & 175\end{array}$

2013 Fisher's $=.000$

$\begin{array}{ccccc}2017 & & & & \\ \text { F } & \text { G } & \text { H } & \text { I } & \text { J } \\ \text { None } & \text { Protestant } & \text { RC } & \text { Other } & \text { Total }\end{array}$

$\begin{array}{ccccc}71 \% & 0 \% & 25 \% & 18 \% & 40 \% \\ 23 \% & 50 \% & 50 \% & 47 \% & 38 \% \\ 0 \% & 50 \% & 25 \% & 35 \% & 20 \% \\ 7 \% & 0 \% & 0 \% & 0 \% & 3 \% \\ & & & & \\ 100 \% & 100 \% & 100 \% & 100 \% & 100 \% \\ 31 & 8 & 20 & 17 & 76\end{array}$

2017 Fisher's $=.000$

$$
A, F=.785 \quad B, G=1.000 \quad C, H=.736 \quad D, I=.494
$$

largest group (34\%) never attended services. An additional $19 \%$ attended services at least once a week. The remaining $3 \%$ selected the "don't know" option.

The information in Table 6 indicates that while there may have been no change in the religious attendance of students between 2013 and 2017, in both surveys, statistically significant differences were evident between students of different faiths. Of students entering Glendon in 2013 those reporting no religion were the most likely to say that they never attended religious services (70\%). (That the response of this group was not $100 \%$ can be perhaps be explained by the fact that the second most mentioned possibility, less than once a week, would also include never.) Among Protestants the majority (52\%) went to services at least once a week. The majority of Roman Catholics (61\%) and Others (57\%) (Muslim, Sikh, Jews, etc.) went to places of worship less than once a week. These differences were statistically significant.

Four years later, in 2017, the pattern was basically the same. Those with no religion were the least likely to attend religious services. Protestants were the most devout. Roughly half of Roman Catholics and adherents to other faiths went to churches, mosques, synagogues, etc. less than once a week. Once again, these faithbased differences were statistically significant.

In both 2013 and 2017 faith-based differences in religious attendance were statistically significant; however, comparisons of religious groups from one survey to the next indicate no statistically significant change over a four-year period. To illustrate, in 2013, 52\% of Protestants went to church at least once a week. The figure for 2017 was 50\%. Among Roman Catholics, in 2013, 57\% went to Mass less than once a week. Four years later the figure had dropped slightly to $50 \%$.

Overall, the information in Tables 3 to 6 suggest the following. Four years at Glendon resulted in no change in the cohort of 2013's students' religious identifications. In addition, there was no change in the frequency with which students participated in religious services. This said, there were clear religious based distinctions in the degree to which students participated in these activities.

\section{Discussion}

Fifty years ago, research conducted in the United States revealed the apostatizing effect of a college/university education on its recipients. Over the years, the effect 
diminished. By the time that the birth cohort of 1965-69 appeared on campus, the effect reached zero. Thereafter, those with higher education actually displayed more religiosity than others. Explanations for this about-face included: changes in reasons for attending university; the spread of post-positive thought; increasingly inclusive admission policies; segregation into moral communities on campuses; and the religious disaffiliation of the less educated.

Unfortunately, similar research was not carried out in Canada. As a result, we are generally unaware of the impact of a university education on the religiosity of young Canadians. Fortunately, at Glendon College, York University, information on aspects of students' religiosity was collected for those who entered the College 1963 and who had completed their studies by 1967 . Through surveys, I obtained similar data for students who entered Glendon in 2013 and who were still on campus in 2017.

Analysis of the information available for the mid-sixties suggests an effect at Glendon similar to that observed in the United States: the campus experience detracted from certain aspects of religiosity. By contrast, fifty years later, the overall effect of the university experience was negligible. This finding parallels the results of much contemporary research conducted on American campuses. How can this phenomenon be explained?

We have seen that a number of students in both the 1967 and 2017 surveys reported religious identifications that were at odds with those of their parents. There is some evidence that the College experience in the period from 1963 to 1967 may have contributed to this severance. The survey of 2017 also revealed differences in the religious identifications of parents and students. This time, however, credit cannot be given to students' experiences over four years of study. As seen earlier, students' religions were no different in 2017 than they had been in 2013. If there had been a break in religious tradition between students and their parents, it must have preceded their first year at Glendon. What would account for this development? A possible explanation is as follows.

Adolescence is a period of identity development. Under certain circumstances, religion can be an important component of an individual's overall identity (Côté, 2016). While the literature on the phenomenon of religious identity is complex, it is sufficient for current purposes to note that schools are a potential locale in which religious identities are negotiated (Moulin, 2013). The more diverse the circumstances under which this negotiation occurs, the greater the probability of varied outcomes.

Consistent with this reasoning, during the period in which the students entering Glendon in 1963 were in high school, there was very little religious diversity in Toronto. There were Protestants (52\%) and there were Catholics (35\%). While both public and Catholic school systems (called the "separate" system) provided secondary school education, most were public. In these, the day may have started with "The Lord's Prayer" and a reading from the Bible. Little more attention than this was given to religion in the curriculum. Nonetheless, Christianity was assumed (Van Arragon, 2015, pp. 162-163). It may not have been until university that students were made aware of different religions and were provided with a forum in which religious ideas could be raised and discussed. For example, some students at Glendon in the 1960s mentioned that until they entered university, they had never known a Jew.

In recent decades it has been different. Recall that Toronto is now home to large numbers of individuals with no religion and/or atheists and agnostics (24\%). Added to this number of non-Christians are Muslims (8\%), Hindus $(6 \%)$, and individuals of many other faiths. Students with backgrounds such as these can be found enrolled in both public and Catholic high schools: Catholicism is not a prerequisite for separate school enrollment (Brown, 2014). As a result, Christianity can no longer be assumed, particularly in the public-school system. Moreover, in many Catholic schools, non-Catholics are not required to participate in religious activities. Indeed, in recognition of emerging practices, the Ontario Human Rights Code now requires that in high schools as elsewhere steps be taken to accommodate students' religious differences (Ontario Human Rights Commission, 2017).

While the Human Rights Code requires religious accommodations, secondary school students can choose to study religion. For example, in grade 11 , students can enroll in a course called "World Religions." This option "introduces students to the range and diversity of world religions and examines how systems of belief affect individual lives and social relationships" (Ministry of Education, 2000, p. 80) (Despite publication date this document reflects current offerings.) Religion is also included in other courses such as "Classical Languages, Level 2" (Ministry of Education, 2000, p. 34). (In the 1960s, no such options were available.) Needless to say, in sepa- 
rate schools, the focus on religion is more intense than in the public system (Assembly of Catholic Bishops of Ontario, 2016).

In this type of environment high school students would be made more aware of religions other than their own than would have been the case in the 1960s. As a result, by the time they enter university, students may have already subjected their beliefs to scrutiny and, in some cases, drifted from the religious identifications of their parents. The consequence may be relatively little religious change during the post-secondary years.

Given that the vast majority of Canadian universities recruit most of their students from their immediate environments, if this explanation has merit, we might expect different effects of the university experience in centers less diverse than Toronto. Studies of Quebec campuses would be particularly interesting. Overall, in that province, there is more emphasis on secularism than elsewhere.

If research of this nature is conducted, we should remember that the American literature is not unanimous. As indicated earlier, there are still some studies that point to the apostatizing effect of higher education. We should not treat these studies as anomalies and base our final conclusions of the college effect on the findings of the majority of studies. Instead, having identified the possibility of different contemporary effects, we should ask under what circumstances each is each manifested. Phenomena to be considered when conducting these inquiries would include the nature of university programs, the characteristics of the population from which students are drawn, and the role of religion in elementary and secondary schools. Clearly, case studies are the way in which a research objective of this nature could best be achieved.

\section{Conclusion}

In this article I employed a strategic narrative to study the effect of the college experience on religiosity at two points in time. In this endeavour, my aim was not to contribute to a theory of religious change. Instead, I used sociological concepts in explaining why the impact of the college experience on religiosity was different in two points in time.

While over the last 50 years Glendon College remained small, and the curriculum continued to have a commitment to liberal education, the nature of the student body and the demographic profile of Toronto changed considerably. In 1963 students entering the College were primarily Protestants of European background. A half century later only a minority were Protestant and, consistent with the population of the City, students of many different national and racial backgrounds could be found on campus.

There were also curricular differences between the two eras. In the mid-sixties it was hard to avoid the issue of religion at Glendon. In the second decade of the current century religion appeared to be a non-issue.

Within this context it is clear that the Glendon experience had a different impact on the cohort of 1963 compared to 2013. Among the former, thoughtful consideration of religious issues was common. As a result, over the course of their studies, the faiths of many students were challenged. When this occurred, students often manifested decreased levels of religiosity. Unfortunately, for the cohort of 1963-67 it is difficult to determine if this decline was revealed in non-affiliation from religion and/ or a change in the intensity of belief. What is clear is a disjunction between the religious identification of parents and some students.

In comparison to students graduating in 1967, those completing their studies in 2017 underwent little change in religious identification or frequency of participation in religious services. This said, in each period, more or less equal numbers reported straying from the religious paths of their parents. Given the absence of change from 2013 to 2017 we must conclude that transformations in religious identification of the 2013 cohort likely occurred prior to university. This possibility suggests that even if in 2013-2017 the study of religion had been more integrated into the overall curriculum, its apostatizing effect might have been minimal.

It is not possible to generalize the findings of this case study to Canadian students in general in either the mid-sixties or fifty years later. Glendon was, and is, a small liberal arts college. Whether the same dynamic was, or is, operative on large campuses with less commitment to the liberal arts is a question that cannot be answered. At best, we might hypothesize similar developments on other small liberal arts campuses. Unfortunately, in Canada, these are few in number. In addition, we could study the effect of different university experiences on the religious identification and practices of contemporary students. 
As noted earlier, Canadians are less devout than Americans, and have been for some time. This said, the declining effect of post-secondary education on religiosity the United States is also evident at Glendon. Hopefully, future research will be able to identify if this is a common phenomenon in Canada, and, if so, the circumstances contributing to this and the alternate outcome.

\section{References}

Assembly of Catholic Bishops of Ontario. (2016). Ontario Catholic secondary curriculum policy document for religious education, grades 9-12. https://iceont. ca/wp-content/uploads/2016/11/Secondary-Religious-Education-Policy-Document-FINAL-MASTER-DOCUMENT-Nov-2016.FINAL-for-PRINT1611-23-minus-COURSE-CODES.pdf

Bell, D. (November 7, 1963). Bell's bullpen, hypocrisy. ProTem, 5.

Bibby, R. W. (2015, October). Religious polarization in Canada: A major empirical update [Paper presentation]. Annual Meeting of the Society for the Scientific Study of Religion, Newport Beach, CA, United States. http://www.reginald bibby.com/images/FINAL SSSR Newport Beach PAPER Tues Oct 2011.30 am.pdf

Brown, L. (2014, August 29). Ontario Catholic schools quietly admitting students of all faiths. The Toronto Star. https://www.thestar.com/yourtoronto/education/2014/08/29/ontario catholic elementary schools quietly admitting students of all faiths. $\underline{\mathrm{html}}$

Calhoun, C. (1998). Explanation in historical sociology: Narrative, general theory, and historical specific theory. American Journal of Sociology, 104(3), 846-871. https://doi.org/10.1086/210089

Caplivitz, D., \& Sherrow, F. (1977). The religious dropouts: Apostasy among college graduates. Sage.

City of Toronto. (2013, May 9). 2011 national household survey: Immigration, citizenship, place of birth, ethnicity, visible minorities, religion and Aboriginal peoples [Press release]. https://www.toronto.ca/wp-content/ uploads/2017/10/9793-2011-NHS-Backgrounder-Im-
migration-Citizenship-Place-of-Birth-Ethnicity-Visible-Minorities-Religion-and-Aboriginal-Peoples-.pdf

Côté, J. (2016). Identify formation, youth, and development. Psychology Press.

Dominion Bureau of Statistics. (1961a). Population: Ethnic groups by age groups [1961 Census of Canada Series 1.3, Bulletin 1.3-2]. https://archive.org/ details/1961925531963engfra

Dominion Bureau of Statistics. (1961b). Population: Religious denominations by age groups (1961 Census of Canada Series 1.3, Bulletin 1.3-3]. https://archive. org/details/1961925541963engfra

Eisgruber, C., \& Zeisberg, M. (2006). Religious freedom in Canada and the United States. International Journal of Constitutional Law, 4(2), 244-268. https:ll doi.org/10.1093/icon/mol004

Fosnacht, K., Sarraf, S., Howe, E., \& Peck, L. K. (2017). How important are high response rates for college surveys? The Review of Higher Education, 40(2), 245-265. https://muse.jhu.edu/article/640611

Gauvreau, M. (2005). The Catholic origins of Quebec's quiet revolution, 1931-1970. McGill-Queen's University Press.

Glendon College. (2017). Message from the principal. http://afpgoldenhorseshoe.org/jobs/director-advancement/glendon-college-york-university

Grayson, J. P. (2011). Remember now thy creator in the days of thy youth: The quiet religious revolution on a Canadian campus in the 1960s. Historical Studies in Education, 23(2), 87-112. https://historicalstudiesineducation.ca/index.php/edu hse-rhe/article/ view/3533

Grayson, J. P. (2014). The experiences and expectations of Canadian female university students in the "Dawn of the Age of Aquarius." Journal of the History of Childhood and Youth, 7(2), 267-294. https://doi. org/10.1353/hcy.2014.0029

Grayson, J. P. (2015). The "feminine mystique" and problems of a cohort of female Canadian university students in the early 1960s. The Sixties: A Journal of History, Politics and Culture, 8(1), 50-74. https:/l www.tandfonline.com/doi/full/10.1080/17541328.20 


\subsection{8}

Grayson, J. P. (2018a). The 'first generation' in historical perspective: Canadian students in the 1960s. Journal of Historical Sociology, 31, 512-525. https:ll onlinelibrary.wiley.com/doi/full/10.1111/johs.12203

Grayson, J. P. (2018b). The life and death of a good idea: Murry Ross's vision for the "new university." Journal of Canadian Studies, 52(3), 624-649. https://www.utpjournals.press/doi/abs/10.3138/ jcs.52.3.2017-0047.r1

Grayson, J. P. (2019). “Plus ça change....": Graduates' views of Canadian females' opportunities after 50 years of change. Canadian Review of Sociology, 56, 49-77. https://onlinelibrary.wiley.com/doi/ abs/10.1111/cars.12230

Guest, M., Aune, K., Sharma, S., \& Warner, R. (2013). Christianity and the university experience: Understanding student faith. Bloomsbury.

Hiemstra, R., \& Stiller, K. (2016). Religious affiliation and attendance in Canada. In Trust Magazine. http:/l www.intrust.org/Magazine/Issues/New-Year-2016/ Religious-affiliation-and-attendance-in-Canada

Hill, J. (2009). Higher education as moral community: Institutional influences on religious participation in college. Journal for the Scientific Study of Religion, 48(3), 515-534. https://onlinelibrary.wiley.com/doi/ abs/10.1111/j.1468-5906.2009.01463.x

Horn, M. (2009). York University: The way must be tried. McGill-Queen's University Press.

Hunsberger, B., \& Brown, L. B. (1984). Religious socialization: Apostasy and the impact of family background. Journal for the Scientific Study of Religion, 23(3), 239-251. https://doi.org/10.2307/1386039

Hunter, J. D. (1983). American evangelicalism: Conservative religion and the quandary of modernity. Rutgers University Press.

Hurtado, S., Sax, L. J., Saenz, V., Harper, C. E., Oseguera, L., Curley, J., Lopez, L., Wold, D. S., \& Arellano, L. (2007). Findings from the 2005 administration of Your First College Year (YFCY): National aggregates. Higher Education Research Institute. http://heri.ucla.edu/PDFs/2005 YFCY REPORT FI- $\underline{\text { NAL.pdf }}$

Lachmann, R. (2013). What is historical sociology? Polity Press.

Lee, J. J., Matzkin, A., \& Arthur, S. (2004). Understanding students' religious and spiritual pursuits: A case study at New York university. https://www.tandfonline.com/doi/abs/10.2202/1940-1639.1377

Lipset, S. M. (1990). Continental divide: The values and institutions of the United States and Canada. Routledge.

Lipset, S. M. (1996). American exceptionalism. W.W. Norton.

Mahoney, J. (2004). Revisiting general theory in historical sociology. Social Forces, 83(2), 459-489. https:// www-library-yorku-ca.ezproxy.library.yorku.ca/find/ MyResearch/EZProxy?qurl=https://www-jstor-org. ezproxy.library.yorku.ca/stable/3598336

Maryl, D., \& Uecker, J. E. (2011). Higher education and religious liberalization among young adults. Social Forces, 90(1), 181-208. https://academic.oup.com/ sf/article-abstract/90/1/181/2235577

Ministry of Education. (2000). The Ontario curriculum crades 11 and 12: Course descriptions and prerequisites. http://www.edu.gov.on.ca/eng/document/ curricul/secondary/descript/descript.pdf

Minn, J., Silverstein, M., \& Gruenewald, T. L. (2018). Intergenerational similarity of religiosity over the family life course. Research on Aging, 40(6), 580-596. https://doi.org/10.1177\%2F0164027517723076

Moulin, D. (2013, November 8-10). Negotiating and constructing religious identities [Paper presentation]. 2013 REA Annual Meeting, Boston, MA, United States. https://www.religiouseducation.net/rea2013/ files/2013/07/Moulin.pdf

National Study of Student Engagement (NSSE). (2018). NSSE 2018 overview. https://nsse.indiana.edu/ nsse/reports-data/nsse-overview-2018.html

Ontario Human Rights Commission. (2017). Policy statement on religious accommodations in schools. http://www.ohrc.on.ca/en/policy-statement-religious-accommodation-schools 
Pew Research Center. (2013). Canada's changing religious landscape. http://www.pewforum. org/2013/06/27/canadas-changing-religious-landscapel

Pew Research Center. (2018). Religious landscape study. http://www.pewforum.org/religious-landscape-studyl

Platt, J. (2007). Some issues in comparative, macro and international work in the history of sociology. The American Sociologist, 38(4), 352-363. https://www. jstor.org/stable/27700517?seq $=1$

Porter, J. (1965). The vertical mosaic. University of Toronto Press.

Ramsay, T. (2013, October 22). Letter from the editor. ProTem, p. 9.

Roberts, L. W., Clifton, R. A., Ferguson, B., Kampen, K., \& Langlois, S. (2005). Recent social trends in Canada, 1960-2000. McGill-Queen's University Press.

Ross, M. G. (1961). The new university. University of Toronto Press.

Schmalzbauer, J. (2007). Campus ministry: A statistical portrait. The Social Science Research Council. http://religion.ssrc.org/reforum/Schmalzbauer.pdf

Schwadel, P. (2014). Birth cohort changes in the association between college education and religious non-affiliation. Social Forces, 93(2), 719-746. https://www.jstor.org/stable/43287843?seq=1

Stryker, R. (1996). Beyond history versus theory. Sociological Methods and Research, 24(30), 304-352. https://journals.sagepub.com/doi/10.1177/00491241 $\underline{96024003003}$

Thiessen, J. (2015). The meaning of Sunday. McGill-Queen's University Press.

Uecker, J., Vaaler, M. L., \& Regnerus, M. D. (2007). Losing my religion: The social sources of religious decline in early adulthood. Social Forces, 85(4), 1667-1692. https://www.jstor.org/stable/4495003?seq $=1$

Van Arragon, L. (2015). "We educate, they indoctrinate": Religion and the politics of togetherness in Onatrio public education [Doctoral dissertation,
University of Ottawa]. Research: University of Ottawa Digital Repository. https://ruor.uottawa.cal bitstream/10393/32206/1/Van Arragon Leo 2015 thesis.pdf

Willits, F. K., \& Crider, D. M. (1989). Church attendance and traditional religious beliefs in adolescence and young adulthood. Review of Religious Research, 31(1), 68-81. https://www-jstor-org.ezproxy.library. yorku.ca/stable/3511025

\section{Contact Information}

\author{
J. Paul Grayson \\ grayson@yorku.ca
}

